\title{
Use Of Altmetric And Bibliometric Indicators To Measure Scientific Productivity In The Fields Of Life And Earth Sciences: Case Study From Haiti
}

\author{
Jasmine Césars, (PhD.) \\ Université Quisqueya, Équipe de recherche sur l’Économie et la Gestion de \\ la Connaissance (EREGeC), Port-au-Prince, Haïti \\ Association Haïtienne Femmes, Science et Techmogie (AHFST), Port-au- \\ Prince, Haïti \\ Magline Alexis, (MSc student) \\ Université Quisqueya, Faculté des Sciences, de Génie et d'Architecture \\ (FSGA), Port-au-Prince, Haïti \\ Équipe de recherche sur l'Économie et la Gestion de la Connaissance \\ (EREGEC) \\ Association Haïtienne Femmes, Science et Techmogie (AHFST), Port-au- \\ Prince, Haïti \\ Evens Emmanuel ,(PhD.) \\ Université Quisqueya, École doctorale “Société et Environnement” (EDSE), \\ Port-au-Prince, Haïti
}

Doi:10.19044/esj.2021.v17n21p316

Submitted: 02 April 2021

Accepted: 14 June 2021

Published: 30 June 2021
Copyright 2021 Author(s)

Under Creative Commons BY-NC-ND

4.0 OPEN ACCESS

Cite As:

Césars J., Alexis M. \& Emmanuel E. (2021). Use Of Altmetric And Bibliometric Indicators To Measure Scientific Productivity In The Fields Of Life And Earth Sciences: Case Study From Haiti. European Scientific Journal, ESJ, 17(21), 316.

https://doi.org/10.19044/esj.2021.v17n21p316

\section{Abstract}

The objective of this study was to carry out, based on certain bibliometric and altimetric indicators, a summary assessment of the scientific productivity of Quisqueya University's researchers in 3 specific fields: agronomy, the environment and health. An experimental framework was designed and implemented based on the quantitative information available on the academic social network ResearchGate, and on SCOPUS and Google scholar, out of a total of 12,731 citations enumerated for Quisqueya University 
as of December 31, 2020, 19\% were for the environment, $19.3 \%$ were for health, $59.9 \%$ for agronomy and $1.8 \%$ for other sectors. All the sectors recorded a significant increase for the RG score altmetric indicator and for the two bibliometric indicators: number of citations and $\mathrm{H}$-index. The data collected were analyzed using XLSTAT and R software. The KolmogorovSmirnov normality test was applied for each of the indicators. Pearson's rank correlation was used to calculate the correlations between the altmetric indicator (RG-Score) from ResearchGate and the bibliometric indicators (citation and H-index) from Google Scholar and Scopus. A significant positive correlation of $\alpha=0.918$ was observed between the number of citations on ResearchGate and on Google Scholar. a result in the same direction $(\alpha=0.991)$ is also observed between the number of citations on ResearchGate and on Scopus. These correlations allow us to conclude that the work of these researchers was cited in publications published in journals referenced in the Web of Science by a rate exceeding $90 \%$.

Keywords: Scientific Productivity, Altmetrics, Bibliometrics, H-Index, Researchgate, RG Score

\section{Introduction}

Over the past decades, the world of knowledge production has found itself in a dynamic of growing competition between researchers, universities, and scientific journals to obtain the highest rankings (Rey, 2009). Indeed, the visibility and impact of the scientific output of universities are now measured by the scientific methods of scientometrics - the tools for the statistical evaluation of research results (Repanovici, 2010). In this process, bibliometrics has become one of the fundamental instruments for measuring not only the performance, but also the international visibility of universities. Bibliometricians have therefore become accustomed to defining a university's research productivity as the number of publications per researcher, distinguishing it from the impact, which they measure by citations (Abramo et al. 2009).

It is assumed that publication is an essential trace of scientific activity and that "notoriety", the fact of being cited, is an indicator of an author's "influence". Who cites who, who is cited by whom and how many times; thus, we calculate an "impact factor" of an author or a group of authors, a laboratory, an institution, etc. (Coutrot, 2008). The analysis of these data highlights a phenomenon of the growth of collaborations which favors both the internationalization and the densification of national and local networks, to the detriment of publications without collaboration, for all disciplines (Maisonobe, 2016). 
The international expansion of the citation of peer-reviewed articles, a tool for measuring scientific productivity, has led to the development of several other indicators to assess the impact of an article. In addition to the $\mathrm{H}$ index (Hirsch, 2005), classical bibliometrics then acquired other evaluation tools, such as the journal impact factor (Garfield, 1994) and the altmetric index of articles (Roemer and Borchardt, 2012).

Moreover, in several industrialized countries, concern for evaluation has become the leitmotif of the discourse governing higher education and research (Charle, 2009). In the countries of the South, the evaluation of research is most often done according to a logic based on how science and power come together. Gaillard and Schlemmer (1996) reported that in both the United States and the South, funding sources have a certain effect which distorts the choices that researchers would have made spontaneously in terms of research priority, according to a rationale and a specifically scientific choice.

In Haiti, the process of evaluating research through the results of projects funded by the government or by international cooperation, has not yet been systematically established within the university system. The notion of measuring scientific productivity using bibliometric and/or altmetric indicators can be considered as a self-regulation that researchers have imposed on themselves to meet new international requirements, by relying on the current dynamics of academic social networks (Emmanuel et al., 2020; Alexis et al., 2020, Joseph et al., 2020). With the intention of assessing the level of involvement of Quisqueya University's researchers in fields related to the agricultural, environmental and health sciences, this study proposes to carry out a summary evaluation of their productivity in the fields selected based on certain bibliometric and altmetric indicators.

\section{Theoretical aspects of measuring scientific productivity. Bibliometrics}

Bibliometrics, a statistical measure named by Pritchard (1969), are used to analyze the quantity and performance of publications. Bibliometrics are a branch of scientometrics - the measurement of scientific and technical research activity - which focuses primarily on the quantitative study of scientific publications for statistical purposes (Gauthier, 1998). It describes the counting and analysis of published scientific research and describes techniques for measuring the scientific impact of research (Pichard, 1969, Roemer and Borchardt, 2012). Bibliometric methods fulfil three main functions, namely description, evaluation, and scientific and technological monitoring (Gauthier, 1998).

Bibliometric indicators have traditionally been used in research evaluations and research performance measurement to determine the impact 
of researchers' research (Hoffman and 2014). In recent years, bibliometrics have raised expectations that it will prove to be a powerful tool for research evaluation. The most widely used bibliometric indicators in measuring a researcher's scientific productivity are the number of citations and the $\mathrm{H}$ index.

\section{Number of citations}

According to Konkiel (2013), the number of citations from a researcher suggests to what extent the results of their work on a given theme influence the subject's discipline. For this author, the citation rate is an indicator of the researcher's performance.

\section{H-index}

Hirsch (2005) defined an index to quantify the results of scientific research of an individual. The $\mathrm{H}$-index is the maximum number $\mathrm{h}$ if $\mathrm{h}$ publications have at least been cited. For Hirsch, the H-index is a useful index to characterize the scientific output of a researcher.

\section{Altmetrics}

According to $\mathrm{Yu}$ et al., (2016), social media has become a popular platform for interacting with the rest of the world, people have changed the way they communicate, distribute information, exchange ideas, and make friends. The advent of Web 2.0 Technology, point out Adriaanse and Rensleigh (2018), social networking tools with enhanced functionalities permeated academia and the research processes of researchers. Indeed, Social media platforms such as blogs, Twitter, Facebook, and article reference managers such as Mendeley are now being used to communicate and discuss research (Chavda and Patel, 2016). Alternative metrics ('altmetrics') is a term used to describe web-based metrics for the impact of scholarly material with an emphasis on social media outlets as a source of data (Priem et al., 2010; Shema et al, 2014; Chavda and Patel, 2016).

\section{ResearchGate}

ResearchGate (RG) was founded in 2008 by Ijad Madisch, who aims to transform the way researchers are doing their research (Dolan, 2012). Nicholas et al. (2016) argued that "RG is a scholarly social network with, arguably, the most comprehensive set of reputation metrics and is, allegedly, the fastest growing of all emerging reputation platforms". According to Singson and Amees (2017), the term academic social networking service is used as a broad term referring to an online service, tool, or platform that can help scholars to build their professional networks with other researchers and facilitate their various activities when conducting research. RG, a this network 
of 20 million members, is interested in the evolution of research and open science, offers researchers and research institutions several indicators, including the RG Score, Total Research Interest and the H-index, allowing them to assess the level of peer reviews of their output in science, and on the science of a particular researcher.

According to

ResearchGate (https://explore.reserchgate.net/display/support/RG+Score), "RG score measures scientific reputation based on how well a researcher's work is received by their peers". The application of the famous rule of peer evaluation freed from constraints established by a publishing house, by research evaluation bodies or by granting organizations, with the particularity for ResearchGate to retain all the research of a researcher, published or not, deserves to be commended. The RG score is calculated based on any contributions a researcher shares on ResearchGate or adds to your profile, such as published articles, unpublished research, projects, questions, and answers. ResearchGate's algorithm examines how peers receive and evaluate these contributions, and who they are. This is because the higher the RG scores of those who interact with a member's searches, the more his own score will increase. The sum of the scores obtained by researchers from a higher education and research institution constitutes the score of that institution for the period under consideration.

The RG score altimetric indicator provides some understanding of the level of peer review of a researcher's research. It appears that the use of this indicator as a measure of a researcher's scientific reputation is not widely accepted by the scientific community. Indeed, studies carried out on the robustness of the model highlight shortcomings preventing the RG score from meeting the claim of serving as a measure of a researcher's scientific reputation. Several studies have identified limitations: (1) the score is not transparent and not reproducible, biases cannot be discovered, and game detection is difficult; (2) the score incorporates the journal impact factor to assess individual researchers, a practice that has been shown to be questionable (Monastersky, 2005; Rossner et al., 2007; Falagas \& Alexiou, 2008; Nicholas et al., 2016). Kraker and Lex (2015) believe that while the goal of RG score as a composite metric that considers social interactions and reputation, alongside traditional metric publications, is desirable, there are limits to the measurement.

Total Research Interest is an indicator created by ReseachGate to gauge the interest that other researchers have in a researcher's work. To calculate this indicator, Researchgate combines several bibliometrics and altmetrics indicators (https://explore.researchgate.net/display/support/Research+Interest). The 
Total Research Interest is based on a weighting system of 4 types of interaction "read, full-text read, recommendation and citation".

\section{Methodology}

\section{Experimental context of the study}

This exploratory study based on the quantitative information available on ResearchGate (www.researchgate.net) on researchers' publications, proposes to assess the scientific productivity of Quisqueya University's (UniQ) researchers in the different scientific fields of the Environment, Agronomy and Health. It considers articles published in national and international journals, with or without an impact factor, and assigning a DOI to the articles they publish or not. The evaluation of the scientific productivity of researchers working in the fields selected is therefore carried out using the following bibliometric indicators (RG score, number of citations, H-index).

In January 2020, the research department launched the project on ResearchGate (www.researchgate.net) titled: "Measuring the scientific productivity of Quisqueya University's researchers on ResearchGate”. The main objectives of this project are: (i) the production of a monthly report in which is compiled all the indicators, i.e. bibliometric and altmetric, communicated by ResearchGate (RG) on the performance of each member of UniQ registered on RG and having an RG score higher than or equal to 1; (ii) publication on Researchgate at the end of each month of a monthly report on the productivity of UniQ researchers on RG; (iii) raising awareness among UniQ members who do not yet have a profile on RG about the bibliometric and altmetric advantages offered by RG and encouraging them to proceed with their registration on this platform (or this academic social network); ( iv) sensitization of researchers about placing their research projects online and updating their profiles, encouragement of researchers to answer questions asked about RG by colleagues working in their respective fields of expertise; (v) encouraging researchers to read the work available on RG in their area of expertise, (vi) encouraging researchers to recommend work available on RG in their area of expertise.

Without wishing to enter into an evaluation of the title and objectives of this project, nor into that of the 12 reports already produced in 2020 (Emmanuel et al, 2020a; Alexis et al, 2020; Emmanuel et al, 2020b; St-Louis et al, 2020; Paul et al, 2020a; Apply et al, 2020; Noncent et al, 2020; Charles et al, 2020; Joseph et al, 2020; Paul et al, 2020b), this initiative provides a contextual and theoretical framework ideal for conducting this study. Indeed, it provides researchers with an empirical database that requires analysis to better understand, in the specific case of this work, the scientific productivity of UniQ researchers in three fields relating to the sciences of the earth and the living. 


\section{Selection, analysis, and modeling of available data}

The 12 RG-report- \# reports provide a list of Quisqueya University members registered on RG. There are professors, assistant professors, research assistants, research interns, and alumni). In January 2020 only 1 researcher in agronomy, 10 in the environment and 9 in health had an RG score higher than or equal to 1.

Let Xi be the RG-Score of each researcher:

$$
\text { RG score total }=\sum_{i=1}^{n} X_{i}
$$

Where the Xi are positive constants greater than 1 .

\section{Methods}

Based on certain bibliometric and altmetric indicators available in academic networks, the objective of this work is to carry out a summary assessment of the scientific productivity of Quisqueya University researchers working in the fields of agronomy, the environment and health. The information compiled in December 2020 by Moïse et al. (2020) for the altmetric indicators from ResearchGate makes it possible to have a sample of 47 researchers with an RG Score higher than 1 . Table 1 shows the representativeness at Quisqueya University of each of the channels selected.

Table 1. Representativeness of the sectors in December 2020

\begin{tabular}{|l|l|l|l|l|l|}
\hline \multicolumn{1}{|c|}{ Fields } & Agronomy & Environment & Health & Others & Total \\
\hline Effective (n) & 5 & 19 & 7 & 16 & 47 \\
\hline Distribution (\%) & 10.64 & 40.43 & 14.89 & 34.04 & 100 \\
\hline
\end{tabular}

The RG Score altimetric indicator provided by the academic social network ResearchGate, and the bibliometric indicators number of citations and H-index available on ResearchGate, Scopus and Google Scholar were collected and recorded (December 31, 2020).

\section{Statistical analysis of data}

Statistical analysis of the data was performed using $\mathrm{R}$ software. Kolmogorov-Smirnov normality tests were performed by XL-STAT software. Pearson's rank correlation was used to calculate correlations between the RG Score altimetric indicator and the citation count and H-index bibliometric indicators that are suitable for non-normal distributions typically used in testing large social media data.

\section{Results and discussion}

The main results obtained within the framework of this summary evaluation of the scientific productivity of Quisqueya University for the year 2020 from the statistical analysis of the altimetric indicator (RG score) 
available on the academic social network ResearchGate and bibliometric indicators (number of citations and H-index) from ResearchGate, Scopus and Google Scholar, concerning the 47 researchers divided into 4 groups (agronomy, environment, health and other disciplines) are presented in the following tables.

\section{Distribution of the RG score altimetric indicator}

The total RG score calculated during the year 2020 for each of the domains selected from the 12 RG-report-\# reports available on ResearchGate is presented in Figure 1.

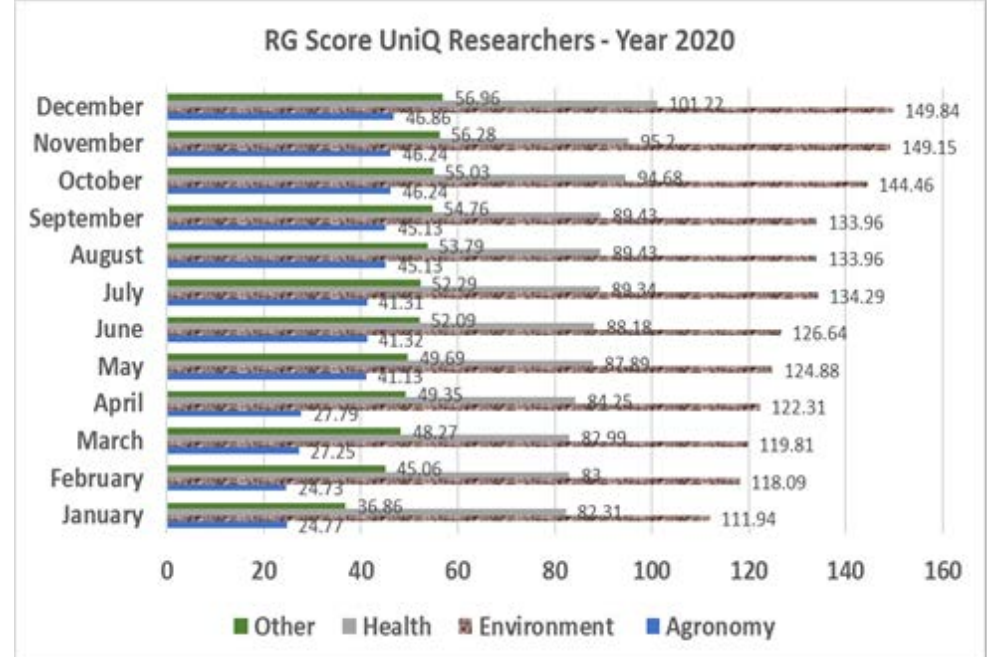

Figure 1. Distribution of the RG Score altimetric indicator during the year 2020

The distribution of the RG score altimetric indicator from January to December 2020 for all researchers at Quisqueya University, as summarized in the table, indicates an increase in the total RG score of 19.09 for agronomy, 18.91 for health, 37.90 for the environment and 20.10 for all other areas. These results on the assessment of contributions for the period selected by the peers demonstrated the order of selectivity of the research areas by the RG score: Environment $>$ Others $>$ Agronomy $>$ Health. Except for agronomy, which had the smallest number of researchers ( $n=5$ see table 1$)$ on December 31, 2020, with an RG score $\geq 1$, the order of appreciation expressed by the peers reflects the order of distribution of the number of researchers per field (see Table 1).

The RG-Score for the environment sector represents $42 \%$ of the RGScore for University Quisqueya. With a total number of researchers lower than that of the environment sector, the health and agronomy sectors together also represented $42 \%$ of the RG-Score of the UniQ (Figure 2). 


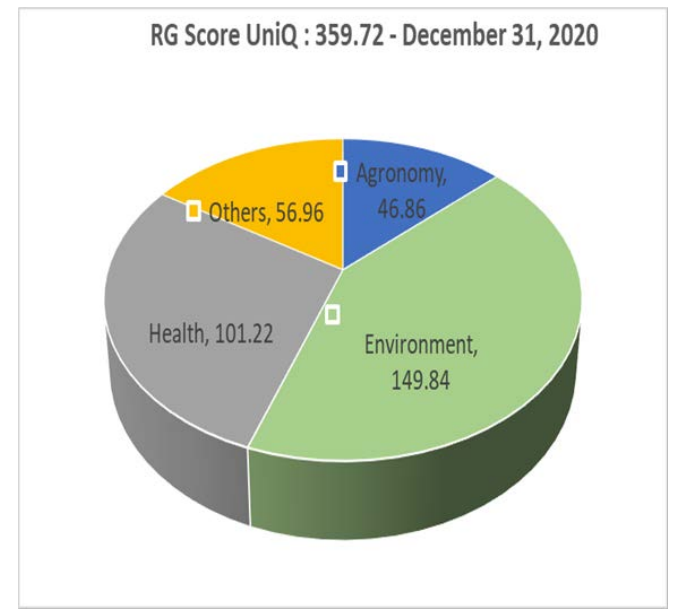

Figure 2. Percentage contribution of fields to the RG score of Quisqueya University - as of December 31, 2020

\section{Distribution of bibliometric indicators (number of citations and $\mathbf{H}$-index)}

Within the framework of this study, two bibliometric indicators were used to measure the scientific productivity of researchers: the number of citations and the $\mathrm{H}$-index. The breakdown of the number of citations as well as that of the H-index of researchers by sector as of December 31, 2020, are presented in Figures 3 and 4.

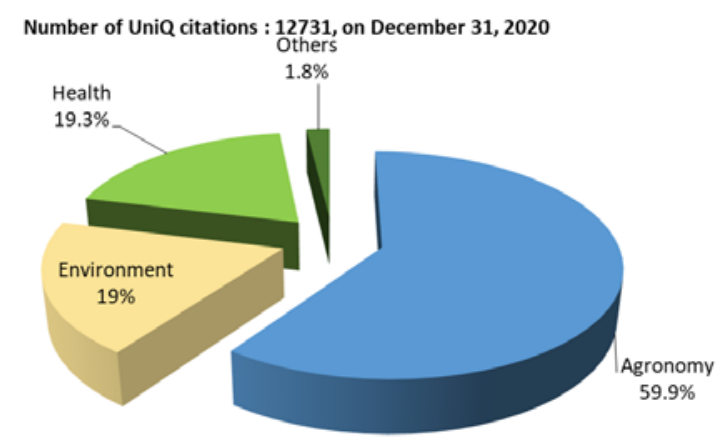

Figure 3. Breakdown of the total number of citations by field on December 31, 2020

Of the total of 12,731 citations enumerated on December 31, 2020, $19 \%$ belong to the environment sector, $19.3 \%$ to health, $59.9 \%$ to agronomy and $1.8 \%$ to other sectors (Figure 3 ). By analyzing the results of the agronomy sector, we see that it has the highest citation average, i.e., 1524.4, as well as the maximum value of citations, which is equal to 7423 . However, these observations allow us to understand that at the level of the agronomy sector, one researcher alone cumulates $97.4 \%$ of the high number of citations in this field. 


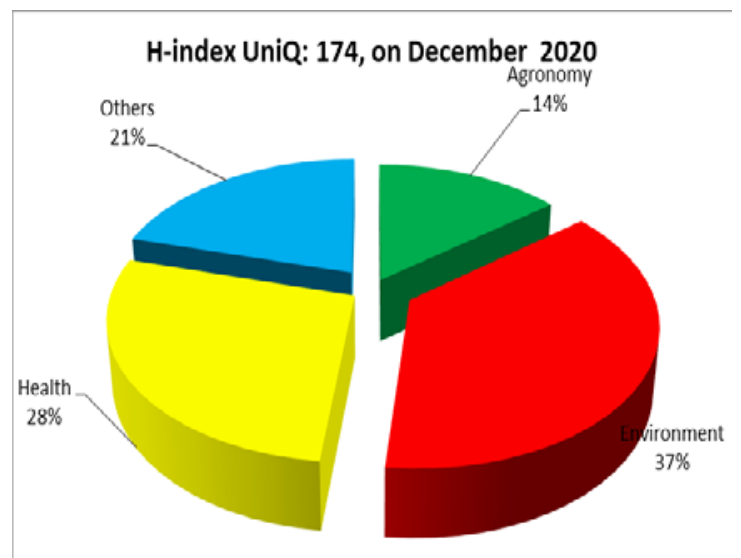

Figure 4. Distribution of the H-index of researchers by field on December 31, 2020

UniQ researchers have a total $\mathrm{H}$-index of 174 . About $42 \%$ belong to the environment, $28 \%$ to health researchers and $14 \%$ to agronomy (Figure 4 ). The distribution of bibliometric indicators for the period from January to December 2020 is summarized in Figures 5 and 6.

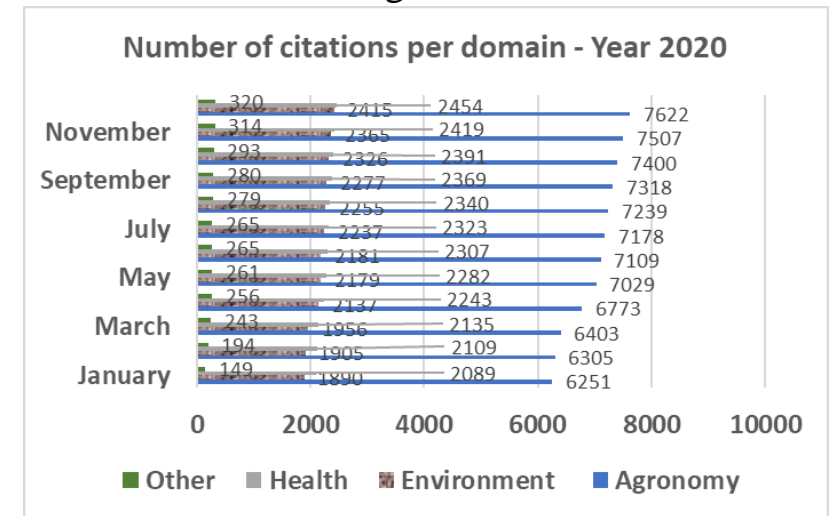

Figure 5. Distribution of the number of citations by domain during the year 2020

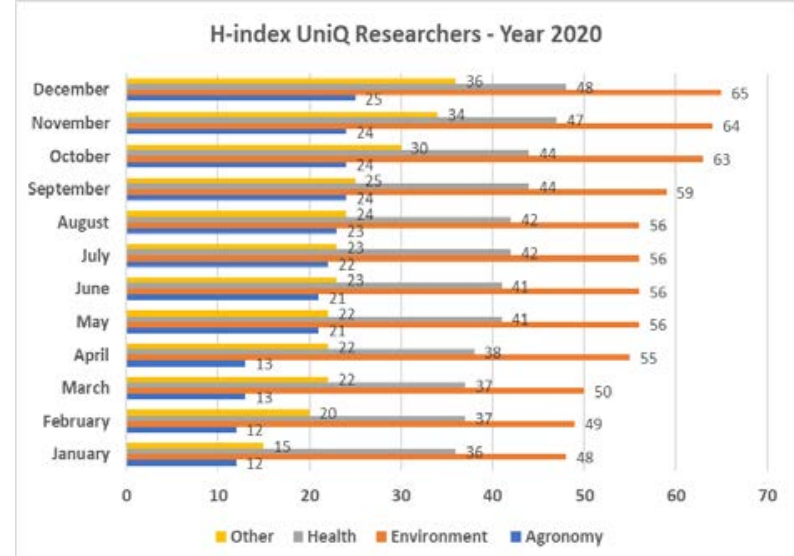

Figure 6. Distribution of the H-index by domain during the year 2020 
The number of citations increased for all the fields studied. Between the information collected in January 2020 and that of December 2020, differences of the order of +1371 for agronomy, +525 for the environment, +365 for health, and +171 for all other areas are indicated. in figure 5. The order of increase of citations for the period selected is expressed as follows: Agronomy $>$ Environment> Health> Others $>$. As for the variation of the $\mathrm{H}$ index, Figure 6 indicates increases of the order of: +21 for other sectors, +17 for the environment, +13 for agronomy and +12 for health. This increase is thus observed between the sectors: Others> Environment> Agronomy> Health.

Analysis of the information presented in Figures 5 and 6 shows a significant increase in value between January and December 2020 for the bibliometric indicators studied in this study. Tables 2 and 3 provide information on the variation in bibliometric indicators (number of citations and $\mathrm{H}$-index) for each of the streams between January and December 2020.

Table 2. Variation of the bibliometric indicator "Number of citations"

\begin{tabular}{|c|c|c|c|}
\hline Field & January 2020 & December 2020 & Variation (\%) \\
\hline Agronomy & 6251 & 7622 & 21.93 \\
\hline Environment & 1890 & 2415 & 27.78 \\
\hline Health & 2089 & 2454 & 17.47 \\
\hline Others & 149 & 320 & 114.77 \\
\hline
\end{tabular}

The distribution results show an increase in total citations (Table 2) of $21.93 \%$ for agronomy, with an increase of 27.78 for the environment, $17.47 \%$ for health and $114.77 \%$ for other fields.

Table 3 summarizes the variation in the estimated $\mathrm{H}$-index results for each sector for the period from January to December 2020. These results indicate an increase in the $\mathrm{H}$-index by sector, generally ranging from $33.33 \%$ to $140 \%$ in total. This increase follows the following order: Others> Agronomy $>$ Environment $>$ Health.

Table 3. Variation of the bibliometric indicator "H-index"

\begin{tabular}{|c|c|c|c|}
\hline Field & January 2020 & December 2020 & Variation (\%) \\
\hline Agronomy & 12 & 25 & 108.33 \\
\hline Environment & 48 & 65 & 35.42 \\
\hline Health & 36 & 48 & 33.33 \\
\hline Others & 15 & 36 & 140.00 \\
\hline
\end{tabular}

\section{Distribution of bibliometric indicators in ResearchGate, Scopus and Google Scholar} Distribution classes of the production index

Martin and Irvin (1985) consider that each indicator has its advantages and limitations, and care should be taken not to view them as "absolute" indices. The convergence of indicators must be tested to put the information they convey into perspective. To better appreciate the information provided 
for the indicators used to calculate the index of the scientific production index, the sample of 47 researchers was broken down into eleven classes of values.

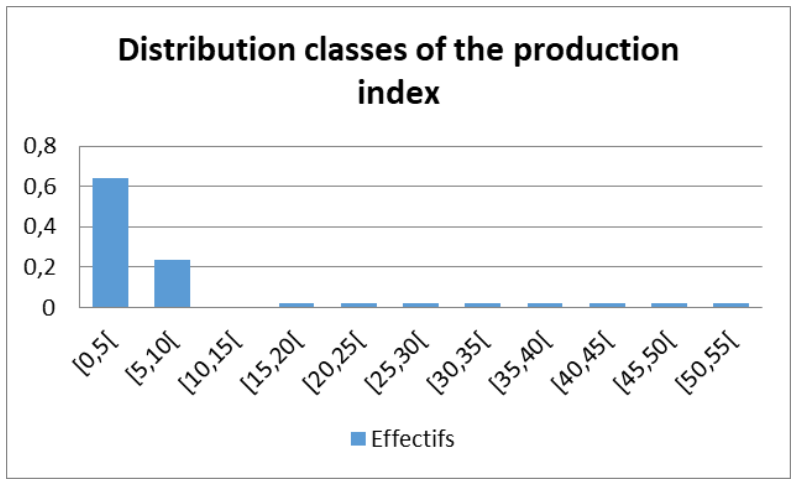

Figure 7. Distribution class of researchers according to their RG Score

The scientific output achieved during the period is very unevenly distributed among UniQ's teacher-researchers. Almost 63.5\% of UniQ researchers have a publication score lower than 5, while only $10.41 \%$ have scores above 10.

\section{Selection of data based on the low number of self-citations.}

To reduce the biases that self-citations can generate on productivity, it was decided to evaluate researchers who meet the following conditions:

RG-Score $\geq 10$

$\mathrm{H}$-index $\geq \mathrm{H}$-index including auto citations.

Of the 47 researchers with an RG score $>1$ in ResearchGate, only 5 met the conditions. They were thus divided: 1 in agronomy, 1 in the environment and 3 in health. The distribution of the RG-Score $\geq 10$ metric indicator is summarized in Figure 8.

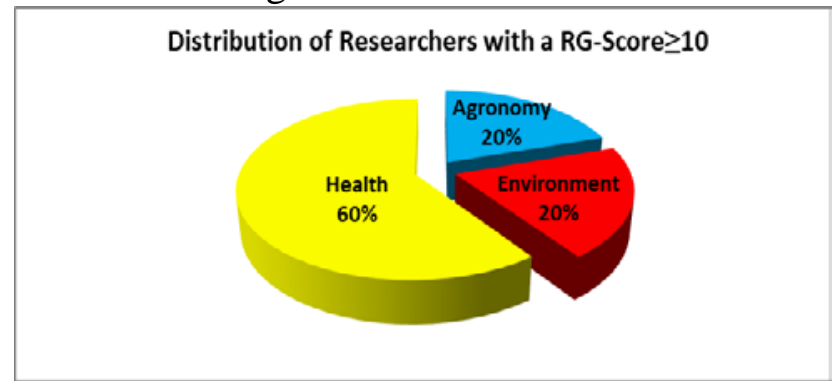

Figure 8. Distribution by field of researchers with an RG Score $>10$

Figure 8 shows that the 2 researchers constituting the population of those in agronomy and the environment with an RG score > 10, represent $40 \%$, while the 3 in health having fulfilled the same conditionality represent $60 \%$. 


\section{Study of the relationship between the RG-Score and the bibliometric indicators available on ResearchGate, Google Scholar and Scopus}

The study of the relationship between the available RG-Score and the bibliometric indicators, available on ResearchGate, Google Scholar and Scopus, respectively, was carried out using data collected manually during the month of December 2020. This is digital information on the RG-Score, the number of citations and the $\mathrm{H}$-index of these researchers. Descriptive statistics for these data are presented in Table 4.

Table 4. Descriptive statistics of the RG score and the bibliometric indicators of researchers

\begin{tabular}{|c|c|c|c|c|c|}
\hline Indicator & Mean & Min & Max & SD & n \\
\hline RG-Score (ResearchGate) & 52.6 & 25.23 & 80.47 & 27.62 & 3 \\
\hline Citations (ResearchGate) & 3856 & 1744 & 7423 & 3106.53 & 3 \\
\hline H-index (ResearchGate) & 22.67 & 13 & 39 & 14.22 & 3 \\
\hline Citations (Google Scholar) & 3226 & 0 & 7560 & 3899.89 & 3 \\
\hline H-index (Google Scholar) & 11.33 & 0 & 19 & 10.02 & 3 \\
\hline Citation (Scopus) & 2570.3 & 1074 & 4677 & 1877.44 & 3 \\
\hline H-index (Scopus) & 7 & 11 & 36 & 6.08 & 3 \\
\hline
\end{tabular}

We note that the average RG Score of the 3 sectors is 52.59 with a low score observed in agronomy. The average citation number in Google Scholar is 3226 with a citation number equal to 0 for the health field. The same goes for the H-index on Google Scholar for health researchers.

The comparison of the number of citations and H-index of these researchers in the various academic social networks makes it possible to postulate that in certain disciplines, for example health, the research professors in the health sciences have not yet created a profile on Google Scholar. More than $70 \%$ of the number of citations made by researchers on Google Scholar are recorded in Agronomy. As a result, UniQ researchers are much more present on ResearchGate than on the other academic social networks considered in this study.

\section{Statistical analysis of data}

Data were analyzed using XLSTAT and R software, including the Kolmogorov-Smirnov normality test for each indicator. Pearson's correlation was used to calculate correlations between the altmetric indicator (RG-Score) from ResearchGate and bibliometric indicators (citation and H-index) from Google Scholar and Scopus.

For applications of the Kolmogorov-Smirnov normality test on the following indicators: a. number of citations (Scopus), b. H-index (Scopus), c. number of citations (Google Scholar), d. H-index (Google Scholar), e. number of citations (ResrearchGate), f. H-index (ResearchGate), the following two hypotheses have been developed:

1. H0: The sample follows a normal distribution. 
2. Ha: The sample does not follow a normal distribution.

The histogram obtained by applying the Kolmogorov-Smirnov normality test for the number of citations available on Scopus for the 3 researchers is shown in Figure 9.

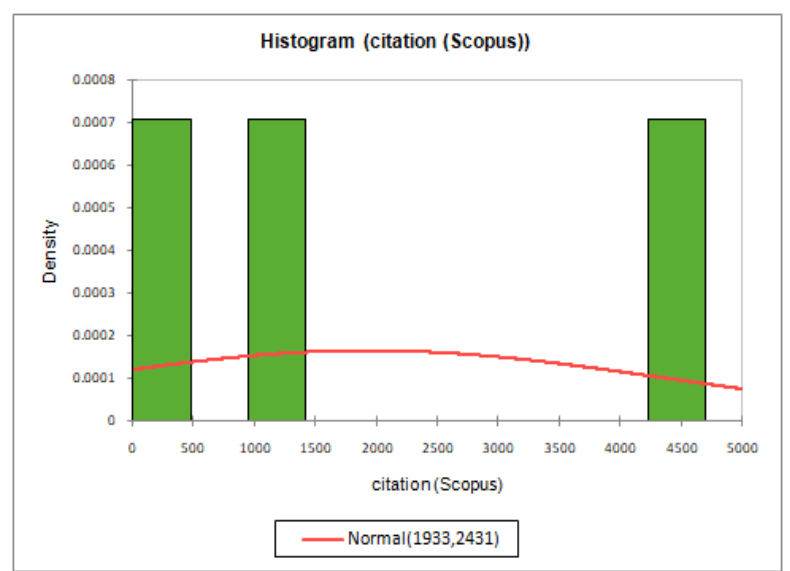

Figure 9. Histogram of the normality test for the number of citations on Scopus

Since the $\mathrm{p}$-value $(\mathrm{p}=0.873)$ calculated is higher than the significance level alpha $=0.05$, we cannot reject the null hypothesis $\mathrm{H} 0$. The same result $(\mathrm{p}>$ alpha $=0.05)$ was also obtained for the 3 other applications.

Distribution of altmetric and bibliometric indicators of these researchers

The distribution of the altimetric indicator as well as the bibliometric indicators for December 2020 for researchers with an RG-Score $\geq 10$ is summarized in Table 5.

Table 5. Distribution of altmetric and bibliometric indicators

\begin{tabular}{|l|l|l|l|l|l|}
\hline & $\begin{array}{l}\text { ResearchGate } \\
\text { RG-Score }\end{array}$ & $\begin{array}{l}\text { Google Scholar } \\
\text { Citation }\end{array}$ & $\begin{array}{l}\text { Scopus } \\
\text { citation }\end{array}$ & $\begin{array}{l}\text { Google } \\
\text { Scholar } \\
\text { H-index }\end{array}$ & $\begin{array}{l}\text { Scopus } \\
\text { H-index }\end{array}$ \\
\hline Normality & 0.99 & 0.93 & 0.87 & 0.76 & 0.61 \\
\hline
\end{tabular}

The results of the distribution of the altimetric indicator on ResearchGate indicate an increase in the total number of citations of $19.53 \%$ compared to Google Scholar and 50.02\% compared to Scopus (Figure 10). 


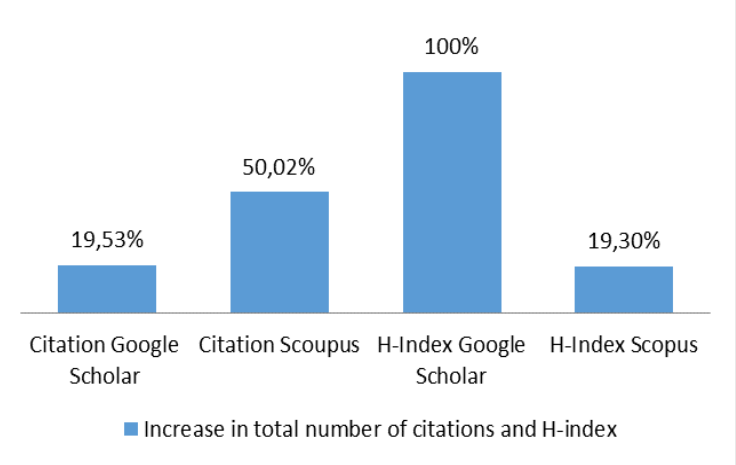

Figure 10. Distribution of the RG Score and increase in the number of citations

\section{Correlation between RG Score and bibliometric indicators}

The relationships between the RG Score altmetric indicator from ResearchGate and the bibliometric indicators of number of citations and the $\mathrm{H}$-index from Google Scholar and Scopus were demonstrated by the Pearson rank correlation coefficient. Table 6 shows the correlation matrix for the analysis of these relationships.

Table 6. Correlation matrix between RG Score and bibliometric indicators (number of citations and H-index)

\begin{tabular}{|c|c|c|c|c|}
\hline $\begin{array}{c}\text { Pearson Rank } \\
\text { Correlation }\end{array}$ & $\begin{array}{c}\text { Google } \\
\text { Scholar } \\
\text { citation }\end{array}$ & $\begin{array}{c}\text { Scopus } \\
\text { citation }\end{array}$ & $\begin{array}{c}\text { Google } \\
\text { Scholar } \\
\text { H-index }\end{array}$ & $\begin{array}{c}\text { Scopus } \\
\text { H-index }\end{array}$ \\
\hline $\begin{array}{c}\text { ResearchGate } \\
\text { RG-Score }\end{array}$ & -0.965 & -0.712 & -0759 & 0.90 \\
\hline $\begin{array}{c}\text { ResearchGate } \\
\text { citation }\end{array}$ & 0.928 & 0.991 & 0.215 & -0.436 \\
\hline $\begin{array}{c}\text { ResearchGate } \\
\text { H-index }\end{array}$ & -0.786 & -0.381 & -0.953 & 0.997 \\
\hline
\end{tabular}

Table 6 gives the results of the Pearson rank correlation for the following 3 indicators RG-Score, citation and H-index provided by ResearchGate for the month of December 2020, with the number of citations on SCOPUS and Google Scholar as well as the H-index available on these two scientific databases.

A significant correlation was observed between the number of citations on RG and the information available on SCOPUS for this same indicator. This result, SCOPUS, Pearson's $r=0.99(<0.05$ significance), leads to the conclusion that the works cited are $99 \%$ those published in journals referenced by SCOPUS or by the Web of Science. The work of Shrivastava \& Mahajan (2015) has shown a correlation of Pearson's $r=0.98$ (significance not listed) between the altmetric indicators of ResearchGate and the citations analysis resources of Scopus. An important correlation $(\mathrm{r}=0.928)$ is also observed between ResearchGate citation and Google Scholar citation. 
The results, Pearson's $r=0.90$ and $r=0.997$ ( $<0.05$ significance $)$ obtained respectively for the correlations of the Pearson ranks between ResearchGate citation and Scopus H-index, between ResearchGate H-index and Scopus H-index, coincide with the orders of magnitudes provided in the legend of the correlation matrix of rank values developed by Adriaanse and Rensleigh (2018) for the bibliometric indicators of SCOPUS, Google Scholar and Web of Science, and the altmetric indicators of RG. These results show that the journals referenced, and which have a factor impact seem to have a weight in the estimation of the RG Score. Furthermore, these results are consistent with the information reported in the literature on the strong positive correlations that exist between the altmetrics indicators of RG and the bibliometric indicators, in particular the number of citations) from Scopus, Web of Science and Google Scholar (Adriaanse and Rensleigh, 2018).

\section{Conclusion}

The objective of this study was to carry out a summary assessment of the scientific productivity of Quisqueya University researchers in 3 specific fields: agronomy, environment, and health. An experimental framework was created using information available on the academic social network ResearchGate, and on SCOPUS and Google scholar. All the fields recorded a significant increase for the RG score altmetric indicator and the two bibliometric indicators: number of citations and $\mathrm{H}$-index.

The strong positive correlations observed between the indicators of RG citation and those of structures like SCOPUS are found in the same orders of magnitude with information reported in the literature. However, strong negative correlations, Pearson's $r=-0.965$ and $r=-0.953$ ( $<0.05$ significance), respectively between RG-Score and Google Scholar citation; and between RG $\mathrm{H}$-index and Google Scholar H-index, were observed. These results, reflecting an opposition of meaning in the evolution of the indicators concerned, need to be studied to identify, from the various variables that enter the estimation of these indicators, elements of response allowing the interpretation of these observations.

This simplistic approach to the assessment of the scientific productivity of researchers in a low-income country will now have to be continued and improved by much more comprehensive measures on a much larger number of fields, universities, and by using new economic, altmetric and bibliometric indicators.

Author Contributions: Conceptualization of the study - Evens Emmanuel. Writing of the original study protocol - Evens Emmanuel. Preparation of the data collection tool - Magline Alexis. Validation of the data collection tool - Evens Emmanuel, Jasmine Césars. Data collection, data 
processing and analysis - Magline Alexis and Jasmine Césars. Writing of the first draft of the paper - Jasmine Césars, Magline Alexis and Evens Emmanuel. Review, editing and revised version - Evens Emmanuel. All the authors have read and agreed to the published version of the manuscript.

Acknowledgments: The authors are thankful to the "One Health" University Space of Quisqueya University, FOKAL-Open Society Foundation Haiti, the Agence universitaire de la Francophonie (AUF), the Representation of the Institute of Research for Development (IRD) in Mexico, Cuba, and Haiti, and the AOG (Association Communautaire Paysanne des Originaires de Grande Plaine), for their support in carrying out this study.

Conflicts of Interest: The authors declare no conflict of interest. The funders had no role in the design of this study; in the collection, analyses, or interpretation of data; in the writing of the manuscript, or in the decision to publish the results.

\section{References}

1. Abramo, G., D’Angelo, C. A., \& Di Costa, F. (2009). Research collaboration and productivity: is there correlation?. Higher education, 57(2), 155-171. https://doi.org/10.1007/s10734-008-9139z

2. Adriaanse, L. S., \& Rensleigh, C. (2018). ResearchGate: Investigating Altmetric and Bibliometric Relationships for Environmental Science Researchers at Unisa. In.: International Conference on Multidisciplinary Research. Track 4: Education. ISBN 978-99949-0384-9. https://core.ac.uk/download/pdf/160827888.pdf

3. Alexis, M., Emmanuel, E., Millien, M. F., Balthazard-Accou, K., Cadet, R. L., \& Jean, G. (2020). Measuring the scientific productivity of UniQ researchers on ResearchGate (February 18, 2020). Report number: RG-report-002. Port-au-Prince: Université Quisqueya. https://www.researchgate.net/publication/340260903_Measuring_the _scientific_productivity_of_UniQ_researchers_on_ResearchGate_Fe bruary_18_2020

4. Apply, A., Joseph, Y., Emmanuel, E. (2020). Measuring the scientific productivity of UniQ researchers on ResearchGate (June 24, 2020). Report number: RG-report-006. Port-au-Prince: Université Quisqueya.

https://www.researchgate.net/publication/342479925_Measuring_the _scientific_productivity_of_UniQ_researchers_on_ResearchGate_Ju ne_24_2020 
5. Charle, C. (2009). L'évaluation des enseignantschercheurs. Vingtième Siècle. Revue d'histoire, (2), 159-170. https://doi.org/10.3917/ving.102.0159

6. Charles, J. R., Letemps, É., \& Emmanuel, E. (2020). Measuring the scientific productivity of UniQ researchers on ResearchGate August 20, 2020. Report number: RG-report-008. Port-au-Prince: Université Quisqueya.

https://www.researchgate.net/publication/343786040_Measuring_the _scientific_productivity_of_UniQ_researchers_on_ResearchGate_Au gust_20_2020

7. Chavda, J., \& Patel, A. (2016). Measuring research impact: bibliometrics, social media, altmetrics, and the BJGP. British Journal of General Practice, 66(642), e59-e61. https://doi.org/10.3399/bjgp16X683353

8. Coutrot, L. (2008). Sur l'usage récent des indicateurs bibliométriques comme outil d'évaluation de la recherche scientifique. Bulletin de méthodologie sociologique. Bulletin of sociological methodology, (100), 45-50. https://journals.openedition.org/bms/3353

9. Dolan, K. A. (2012). How Ijad Madisch aims to disrupt science research with a social network. Lists. Forbes. http://www.forbes.com/sites/kerryadolan/2012/07/19/how-ijadmadisch-aims-to-disrupt-science-researchwith-a-social-network/.

10. Emmanuel, E., Cadet, R.L., Balthazard-Accou, K., Jean, G., Millien, M.F. (2020a). Measuring the scientific productivity of UniQ researchers on ResearchGate (January 21, 2020). Report number: RGreport-001. Port-au-Prince: Université Quisqueya. https://www.researchgate.net/publication/340260793_Measuring_the _scientific_productivity_of_UniQ_researchers_on_ResearchGate_Jan uary_21_2020

11. Emmanuel, E., Cadet, R.L., Balthazard-Accou, K., Jean, G., Millien, M.F. (2020b). Measuring the scientific productivity of UniQ researchers on ResearchGate (March 17, 2020). Report number: RGreport-003. Port-au-Prince: Université Quisqueya https://www.researchgate.net/publication/340260694_Measuring_the _scientific_productivity_of_UniQ_researchers_on_ResearchGate_Ma rch_17_2020

12. Falagas, M. E., \& Alexiou, V. G. (2008). The top-ten in journal impact factor manipulation. Archivum immunologiae et therapiae experimentalis, 56(4), 223-226. https://doi.org/10.1007/s00005-0080024-5 
13. Gaillard, J., \& Schlemmer, B. (1996). Chercheurs du nord, chercheurs du sud: Itineraires, pratiques, modeles. Les Sciences Au Sud. Etat Des Lieux. ORSTOM, Paris, 113-135.

14. Gauthier, É. (1998). Bibliometric analysis of scientific and technological research: a user's guide to the methodology. Ottawa: Observatoire des Sciences et des Technologies. Working paper. http://www.publications.gc.ca/Collection/Statcan/88F0006X/88F000 6XIE1998008.pdf

15. Garfield, E. (1994). The impact factor. Current contents, 25(20), 3-7.

16. Hirsch, J. E. (2005). An index to quantify an individual's scientific research output. Proceedings of the National academy of sciences, 102(46), 16569-16572.

17. Hoffmann, C. P., Lutz, C., \& Meckel, M. (2014, January). Impact factor 2.0: Applying social network analysis to scientific impact assessment. In 2014 47th Hawaii International Conference on System Sciences (pp. 1576-1585). IEEE.

18. Joseph, I., Moise, K., Emmanuel, E. (2020). Measuring the scientific productivity of UniQ researchers on ResearchGate (September 24, 2020). Report number: RG-report-009. Port-au-Prince: Université Quisqueya.

https://www.researchgate.net/publication/344380700_Measuring_the _scientific_productivity_of_UniQ_researchers_on_ResearchGate_Se ptember_24_2020

19. Joseph, I., Moise, K., \& Emmanuel, E. (2020). Measuring the scientific productivity of UniQ researchers on ResearchGate September 24, 2020. Report number: RG-report-009. Port-au-Prince: Université Quisqueya.

20. https://www.researchgate.net/publication/344380700_Measuring_the _scientific_productivity_of_UniQ_researchers_on_ResearchGate_Se ptember_24_2020

21. Konkiel, S. (2013). Altmetrics: A 21st-century solution to determining research quality. Online searcher, 37(4), 10-15.

22. Kraker, P., \& Lex, E. (2015). A critical look at the ResearchGate score as a measure of scientific reputation. Proceedings of the Quantifying and Analysing Scholarly Communication on the Web Workshop (ASCW'15), Web Science Conference, Oxford, England, 28 June-1 July 2015.

23. Lamari, M., Villeneuve, C., \& Gélinas, P. (2010). Financement de la recherche universitaire et productivité scientifique des chercheurs au Québec.

https://www.academia.edu/download/29090255/Tire_a_part_article2. pdf 
24. Maisonobe, M., Grossetti, M., Milard, B., Eckert, D., \& Jégou, L. (2016). L'évolution mondiale des réseaux de collaborations scientifiques entre villes: des échelles multiples. Revue française de sociologie, 57(3), 417-441. https://doi.org/10.3917/rfs.573.0417

25. Martin, B. R., \& Irvine, J. (1983). Assessing basic research: some partial indicators of scientific progress in radio astronomy. Research policy, 12(2):61-90. https://doi.org/10.1016/0048-7333(83)90005-7

26. Monastersky, R. (2005). The number that's devouring science. Chronicle of Higher Education, 52(8), 14. https://www3.nd.edu/ pkamat/citations/chronicle.pdf

27. Nicholas, D., Clark, D., \& Herman, E. (2016). ResearchGate: reputation uncovered. Learned Publishing, 29(3), 173-182. https://onlinelibrary.wiley.com/doi/epdf/10.1002/leap.1035

28. Noncent, D., Pierre, A., Garçon, J., Emmanuel, E. (2020). Measuring the scientific productivity of UniQ researchers on ResearchGate (July 24, 2020). Report number: RG-report-007. Port-au-Prince: Université Quisqueya.

https://www.researchgate.net/publication/343206205_Measuring_the _scientific_productivity_of_UniQ_researchers_on_ResearchGate_Jul y_24_2020

29. Paul, B., Joseph, E., Jeune, W., Alexis, M., Benjamin, F.,Michel, D., Apply, A., St-Louis, D., Emmanuel, E. (2020a). Measuring the scientific productivity of UniQ researchers on ResearchGate (May 21, 2020). Report number: RG-report-005. Port-au-Prince: Université Quisqueya.

https://www.researchgate.net/publication/341591842_Measuring_the _scientific_productivity_of_UniQ_researchers_on_ResearchGate_Ma y_21_2020

30. Paul, B., Moïse, K., Henrys, H.J., Emmanuel, E. (2020b). Bibliometric and altmetric datas from the academic social network ResearchGate on Quisqueya University, October 22, 2020. RG-monthly report: RGreport-010. Port-au-Prince: Université Quisqueya. https://www.researchgate.net/publication/344828048_Bibliometric_a nd_altmetric_datas_from_the_academic_social_network_ResearchGa te_on_Quisqueya_University_October_22_2020

31. Priem J, Taraborelli D, Groth P, Neylon C. (2010). Altmetrics: A manifesto. http://altmetrics.org/manifesto

32. Pritchard, A. (1969). Statistical bibliography or bibliometrics. Journal of documentation, 25(4):348-349.

33. Repanovici, A. (2010). Mesure de la visibilité de la production scientifique de l'Université à l'aide de Google Scholar, du logiciel "Publish or Perish" et des methodes de la scientométrie. World Library 
and Information Congress: 76th IFLA General Conference and Assembly 10-15 August 2010, Gothenburg, Sweden. http://origin.ifla.org/past-wlic/2010/155-repanovici-fr.pdf

34. Rey, O. (2009). Productivité et qualité scientifique: avec quelles publications compter? Scientific productivity and quality: identifying relevant publications” Dossier d'actualité de la VST, n 46 - juin-juillet 2009

35. Roemer, R. C., \& Borchardt, R. (2012). From bibliometrics to altmetrics: A changing scholarly landscape. College \& Research Libraries News, 73(10), 596-600. https://crln.acrl.org/index.php/crlnews/article/view/8846/9480

36. Rossner, M., Van Epps, H., \& Hill, E. (2008). Show me the data.J Gen Physiol (2008) 131 (1): 3-4. https://doi.org/10.1085/jgp.200709940

37. Shrivastava, R., \& Mahajan, P. (2015). Relationship amongst ResearchGate altmetric indicators and Scopus bibliometric indicators: The case of Panjab University Chandigarh (India). New Library World. Vol. 116 No. 9/10, pp. 564-577. https://doi.org/10.1108/NLW03-2015-0017

38. Shema, H., Bar-Ilan, J., \& Thelwall, M. (2014). Do blog citations correlate with a higher number of future citations? Research blogs as a potential source for alternative metrics. Journal of the Association for information science and technology, 65(5), 1018-1027. https://doi.org/10.1002/asi.23037

39. Singson, M., \& Amees, M. (2017). Use of ResearchGate by the Research Scholars of Pondicherry University: A Study. DESIDOC Journal of Library \& Information Technology, 37(5). DOI : 10.14429/djlit.37.11139.

40. St-Louis, D., Benjamin, F., Michel, D., Jean, G., Apply, A., Ciguino, H., Casséus, R.M., Alexis, M., Cadet, R.L., Emmanuel, E. (2020). Measuring the scientific productivity of UniQ researchers on ResearchGate (April 21, 2020). Report number: RG-report-004. Portau-Prince: Université Quisqueya. https://www.researchgate.net/publication/340826414_Measuring_the _scientific_productivity_of_UniQ_researchers_on_ResearchGate_Ap ril_21_2020

41. Yu, M. C., Wu, Y. C. J., Alhalabi, W., Kao, H. Y., \& Wu, W. H. (2016). ResearchGate: An effective altmetric indicator for active researchers?. Computers in human behavior, 55, 1001-1006. https://doi.org/10.1016/j.chb.2015.11.007 